Published in final edited form as:

Curr Top Microbiol Immunol. 2010 ; 347: 21-41. doi:10.1007/82_2010_68.

\title{
Oncogenic Mutations of PIK3CA in Human Cancers
}

\author{
Yardena Samuels and \\ Cancer Genetics Branch, National Human Genome Research Institute, National Institutes of \\ Health, Bethesda, MD, USA, samuelsy@mail.nih.gov \\ Todd Waldman \\ Department of Oncology, Lombardi Comprehensive Cancer Center, Georgetown University \\ School of Medicine, Washington, DC, USA
}

\begin{abstract}
The involvement of the PIK3CA gene product p110a, the catalytic subunit of phosphatidylinositol 3-kinase (PI3K), in human cancer has been suggested for over 15 years, and support for this proposal had been provided by both genetic and functional studies, including most recently the discovery of common activating missense mutations of PIK3CA in a wide variety of common human tumor types. This chapter will focus on the discovery of these mutations and describes their relevance to a wide range of common human tumor types.

Of note, the identification and functional analysis of the PIK3CA gene are reviewed in other chapters in this book. However, a brief mention will be made here of its general properties as background to our focus on the discovery of its cancer-specific mutations.
\end{abstract}

\section{Introduction}

Phosphoinositide kinases (PIKs) are lipid kinases that phosphorylate the inositol ring of phosphoinositides, thus acting as signal transducers. Depending on the phosphorylation site on the carbohydrate, PIKs are categorized into three families: phosphoinositide 3-kinases (PI3Ks), phosphoinositide 4-kinases (PIP4Ks) and phosphoinositide 5-kinases (PIP5Ks). PI3Ks are further grouped into classes I, II or III, depending on their subunit structure, their regulation and their substrate selectivity. Class I PI3Ks, are composed of two subgroups, IA and IB (Vanhaesebroeck and Waterfield 1999). The class IA PI3K subgroup consists of three catalytic subunits: $\mathrm{p} 110 \alpha, \mathrm{p} 110 \beta$, and $\mathrm{p} 110 \delta$ that form heterodimers with one of five regulatory domains: $\mathrm{p} 85 \alpha, \mathrm{p} 85 \beta, \mathrm{p} 85 \gamma, \mathrm{p} 50 \alpha$, and $\mathrm{p} 55 \alpha$. These PI3Ks are activated by cellsurface receptor tyrosine kinases. PI3Ks IA and IB catalyze the formation of PtdIns $(3,4,5) \mathrm{P}_{3}$ (PIP3), a process that is reversed by the action of the lipid phosphatase, PTEN. PIP3 serves as an anchor for Pleckstrin homology (PH) domain-containing proteins such as the serine/threonine kinases AKT1, AKT2, and AKT3, which, once localized to the membrane, get activated by 3-phosphoinositide dependent protein kinase-1 (PDK1). AKT has numerous protein targets, including mTor, Bad, Caspase 9, Tuberin, GSK3 $\beta$, and a subset of forkhead transcription factors. The biological consequences of AKT activation are broad and can be subdivided into regulation of cell proliferation, survival and motility (Cantley 2002; Katso et al. 2001; Vivanco and Sawyers 2002).

(C) Springer-Verlag Berlin Heidelberg 2010

Correspondence to: Yardena Samuels. 


\section{Links Between the PI3K Pathway and Cancer}

The role of PI3Ks and specifically p110 $\alpha$ in cancer was implicated when its kinase activity was shown to be associated with viral oncoproteins (Cantley et al. 1991). This was further substantiated by the discovery that some avian and murine retroviruses encode oncogenic derivatives of the cellular PIK3CA and Akt genes, respectively (Bellacosa et al. 1991; Chang et al. 1997; Staal 1987).

Furthermore, PTEN (phosphatase and tensin homolog), which reverses the reaction catalyzed by PI3Ks by dephosphorylating 3-position on inositol head groups, was found to be a tumor suppressor gene commonly mutated in human tumors (Li et al. 1997; Steck et al. 1997) resulting in constitutive activation of the PI3K pathway.

Other investigations showed the amplification of genomic regions containing AKT or PIK3CA genes (Actor et al. 2002; Bastian et al. 1998; Bellacosa et al. 1995; Cheng et al. 1992, 1996; Knobbe and Reifenberger 2003; Shayesteh et al. 1999; Staal 1987; Thompson et al. 1995) in various cancer types with the implication that PI3K was functioning as an oncogene. In addition, mutations in $\mathrm{p} 85$, the regulatory subunit of PI3K, in ovarian and colon tumors have been reported (Philp et al. 2001). Furthermore, the fact that the downstream targets of AKT, such as the forkhead transcription factors FKHR and FKHRL1 have been shown to be translocated in several tumor types (Barr et al. 1993) provides strong evidence that this pathway plays a major role in neoplasia.

\section{High Throughput Sequencing of Gene Families in Human Cancer}

These discoveries suggested that PI3K might be genetically altered in human cancer. One way to definitely implicate a gene in human cancer is to discover tumor-specific mutations in the gene and to evaluate the functional effects of those mutations. This type of mutation search involves direct sequencing of gene(s) in a panel of tumors to identify variations from a reference sequence. The patient's constitutional DNA is then analyzed to determine whether the variant arose specifically within the tumor, i.e., whether the change is somatic.

In the past, technical hurdles have limited the ability to perform mutational analysis of candidate genes in a high throughput fashion. Several important advances have aided the development of high throughput approaches for DNA sequencing and mutation detection in human cancer. The first has been the collection and isolation of high-quality tumor tissue for these analyses, either through generation of early passage tumor cell lines or through selective capture or microdissection of neoplastic tissue. This has permitted the sensitive detection of somatic mutations that would otherwise have been masked by contaminating normal tissue. The second advance has been the delineation of the sequence of the human genome coupled with progress in automated methods for large-scale sequence analysis of specific loci. These methods have been optimized to provide rapid and robust sequence analysis of nearly all exonic regions in the human genome (Jones et al. 2008; Parsons et al. 2008; Sjoblom et al. 2006; Wood et al. 2007). Finally, several methods for automated mutation detection have been developed and applied for analysis of somatic alterations in cancer (Bardelli et al. 2003; Stephens et al. 2006). By direct comparison of sequence chromatograms from tumor and normal tissues, these methods have allowed the sensitive identification of most types of somatic sequence alterations. The combination of these advances has now created an opportunity for systematically identifying somatic mutations in human cancers and evaluating the roles of such mutated genes in tumorigenesis. 


\section{PIK3CA is Somatically Mutated in Colorectal Cancer}

The clear link between the PI3K pathway and cancer noted above stimulated a study to determine whether PI3K genes are genetically altered in human tumors. To do this, a high throughput sequencing approach was used to sequence all of the PI3K genes in a panel of 35 colorectal cancers and corresponding normal tissues. Sequencing of the exons encoding the kinase domain of all 16 members of the PI3K family showed that PIK3CA was the only gene to harbor somatic (i.e., tumor specific) mutations. Sequencing the rest of the gene in 199 additional colorectal cancers revealed that PIK3CA is somatically mutated in $32 \%$ of cases (Samuels et al. 2004). All but three of the alterations were heterozygous and no truncating or nonsense alterations were observed, which is consistent with the mutational signature of oncogenes. To determine at what stage of colorectal cancer PIK3CA mutations occur, 76 premalignant colorectal tumors were also examined. This identified only two mutations, both in advanced adenomas, suggesting that PIK3CA mutations arise late in tumorigenesis, just before or concurrent with invasion.

Importantly, over $80 \%$ of the somatic missense mutations were found in the kinase and helical domains of the PIK3CA subunit. This discovery of "hotspot" mutations is reminiscent of alterations in other oncogenes such as KRAS and BRAF (Bos et al. 1987; Davies et al. 2002; Rajagopalan et al. 2002). Further evaluation of PIK3CA mutational status in colon cancer has since been performed by several other groups and is described in more detail later.

Indeed, this discovery was surprising because despite extensive characterization of this pathway at the biochemical and biological levels, PIK3CA was not known to be mutated in human cancer.

\section{PIK3CA is Mutated in a Wide Variety of Human Tumor Types}

The initial discovery of PIK3CA mutations in colon cancer led to the examination of PIK3CA mutations in additional cancer types. These data and clinicopathological correlations for a subset of the most common tumor types or those with common mutations of PIK3CA are described below. Though amplifications of PIK3CA have been identified in numerous tumor types as well, the description below focuses virtually exclusively on studies that have evaluated mutations of PIK3CA. Of note, the descriptions below include only published studies. However, the Sanger Institute Cancer Genome Project has sequenced PIK3CA in a large number of additional samples. These data are continuously updated, publically available, and can be accessed at http://www.sanger.ac.uk/genetics/CGP/cosmic.

\section{Breast cancer}

In the paper describing the initial discovery of PIK3CA mutations in cancer, PIK3CA mutations were also identified in $1 / 12$ breast cancers (Samuels et al. 2004). However, due to the relatively small number of samples studied and the fact that, despite years of effort, a commonly mutated breast cancer oncogene had not yet been discovered, several groups immediately initiated more comprehensive mutational analyses of PIK3CA in breast cancer (Bachman et al. 2004; Campbell et al. 2004; Lee et al. 2005; Levine et al. 2005; Saal et al. 2005; Wu et al. 2005b).

These efforts were immediately rewarded with very large number of mutations, making it immediately clear that PIK3CA was the most commonly mutated oncogene yet discovered in breast cancer. It is now appreciated that mutations of PIK3CA are found in $25-40 \%$ of all human breast cancers. This discovery was particularly gratifying since it had long been known that the PI3K pathway was often activated in breast cancer via phosphorylation of 
Akt (Page et al. 2000), yet in the absence of frequent PTEN mutations, the mechanism for the activation of Akt remained elusive. Therefore, the presence of PIK3CA mutations provided a molecular explanation for this long-standing conundrum.

Since the initial discovery of PIK3CA mutations in breast cancer, substantial effort has been expended in an attempt to correlate PIK3CA mutations in breast cancer with clinicopathological parameters such as estrogen receptor (ER)/progesterone receptor (PR) positivity, the presence of lymph node metastases, and response to therapy. These relationships are summarized below; however, it is worth noting that there are conflicting data on many of these proposed relationships.

Saal et al. were the first group to propose definitive clinicopathological correlates to PIK3CA mutations in breast cancer (Saal et al. 2005). Their data indicated that PIK3CA mutations were most often present in tumors with intact, expressed PTEN genes; in tumors that had metastasized to lymph nodes; and in tumors with expression of the ER, PR, and ERBB2. Data from Stemke-Hale et al. also demonstrated that PIK3CA mutations were more common in hormone receptor positive and HER2-positive breast cancers (Stemke-Hale et al. 2008). Li et al. confirmed and extended several of these relationships, demonstrating that PIK3CA mutation correlated with worse survival and that mutations were more commonly found in larger tumors with ER and PR expression ( $\mathrm{Li}$ et al. 2006). Lerma et al. and Lai et al. also confirmed the association between PIK3CA mutation and poorer survival (Lai et al. 2008; Lerma et al. 2008). However, these data correlating PIK3CA mutation with poorer survival are controversial, as Barbareschi et al. suggested that whereas exon 9 mutations are associated with poor prognosis, exon 20 mutations are associated with better prognosis (Barbareschi et al. 2007). Furthermore, Maruyama et al. and Perez-Tenorio suggested that PIK3CA mutations are actually associated with better survival (Maruyama et al. 2007; Perez-Tenorio et al. 2007).

Buttita et al. provided another potentially important clinicopathological correlate - that PIK3CA mutations were more commonly found in lobular breast cancers than in ductal breast cancers (Buttitta et al. 2006). Barbareschi et al. found a similar correlation, but suggested that it was specific to samples with mutations in exon 9 (Barbareschi et al. 2007).

PIK3CA mutational status has also been correlated with response to therapy in breast cancer. For example, Berns et al. have suggested that oncogenic mutations of PIK3CA may render breast cancers more resistant to treatment with the antibody-based therapeutic trastuzumab (Berns et al. 2007), and Eichhorn et al. have shown that mutational activation of PIK3CA similarly render cells more resistant to the anti-HER2 agent Lapatinib (Eichhorn et al. 2008). In contrast, Liedtke et al. demonstrated no relationship between PIK3CA mutational status and sensitivity to standard regimens of anthracyline and paclitaxel-based chemotherapy (Liedtke et al. 2008).

\section{Colon cancer}

The initial paper describing the novel discovery of PIK3CA mutations reported the sequence of the entire coding region of the gene in 234 colon tumors and identified a mutation frequency of $32 \%$ (Samuels et al. 2004). This remains the most comprehensive mutational analysis of PIK3CA mutations in colon cancer because of the large number of samples studied and the fact that all 20 exons were sequenced in every sample. Interestingly, in this study mutations were twice as common in tumors with microsatellite instability (RER+) than in tumors that were proficient for DNA repair (RER-).

There is some disagreement in the literature as to whether PIK3CA mutational status correlates with RER status. Whereas Abubaker et al. confirmed the work of Samuels et al. 
by demonstrating a clear relationship between PIK3CA mutation and microsatellite instability (Abubaker et al. 2008a), Velho et al. disagreed, suggesting that PIK3CA mutations occur at roughly equivalent frequencies in RER+ and RER- tumors (Velho et al. 2005). However, Velho et al. reported an unusually low PIK3CA mutation frequency in their samples (14\%).

In addition to RER status, several studies have correlated PIK3CA mutation status to other pathological parameters. For example, Mikami et al. performed an interesting study demonstrating that while PIK3CA mutations were frequently found in the common "protruded-type" of colon cancer, they were very uncommon in the rare "flat-type" colon cancers (Mikami et al. 2006). Miyaki et al. asked whether PIK3CA mutations were found at different frequencies in sporadic colon cancers and those from patients with inherited colon cancer predisposition (Miyaki et al. 2007). They concluded that PIK3CA mutations occurred at similar frequency in sporadic and inherited tumors, but that mutations in patients with inherited predisposition occurred predominantly in the kinase domain whereas mutations in sporadic cases occurred predominantly in the helical domain. This group also confirmed the work of Samuels et al. demonstrating that preinvasive colon tumors generally harbor wildtype PIK3CA genes. Finally, Benvenuti et al. showed that PIK3CA mutations are more prevalent in colorectal cancers from women than from men (Benvenuti et al. 2008).

Several groups have also attempted to correlate PIK3CA mutation status with survival and response to therapy. Several groups have clearly shown that PIK3CA mutation is correlated with poor prognosis, even in patients whose tumor had been completely resected (Barault et al. 2008; Kato et al. 2007; Ogino et al. 2009). Ogino et al. further demonstrated that this effect was dependent on K-Ras mutational status; the presence of PIK3CA mutation conferred no significant effect on mortality among patients with tumors harboring K-Ras mutations. As such, they suggested that clinical trials of PI3K inhibitors may need to be stratified by K-Ras mutational status to accurately assess the efficacy of the inhibitors. Finally, both Jhawer et al. and Sartore-Bianchi et al. showed that colon cancer cells with mutant PIK3CA genes tended to be resistant to therapeutic anti-EGFR antibodies (Jhawer et al. 2008; Sartore-Bianchi et al. 2009).

\section{Endometrial cancer}

Endometrial cancer has proven to be one of the most interesting tumor types for the identification and study of PIK3CA mutations, both because of the high frequency of mutations and the novel finding that PIK3CA mutations are often coincident with PTEN mutations in this tumor type. Oda et al. reported a high frequency of mutations of PIK3CA in uterine endometrioid cancer (36\%), which is all the more remarkable because they sequenced only the exons containing mutational hotspots, so the actual mutation frequency is likely to be somewhat higher (Oda et al. 2005) And, despite initial reports that PIK3CA activation and PTEN inactivation were mutually exclusive, this group identified coincident mutations of PIK3CA and PTEN in 26\% of samples. Remarkably, PIK3CA mutations were actually more common in tumors with mutant PTEN genes than in tumors with wild-type PTEN genes. This study was the first study to suggest that hyperactivation of PI3K signaling by coincident mutations in two members of the pathway could be conducive to tumorigenesis. This was especially intriguing because of the widespread belief that hyperactivation of oncogenic signaling pathways such as PI3K can thwart cancer pathogenesis by inducing p53-dependent senescence (Chen et al. 2005; Kim et al. 2007). These data reporting coincident mutations in PIK3CA and PTEN were then supported by three additional groups (Hayes et al. 2006; Kang et al. 2008; Velasco et al. 2006). Of note, one group has reported a somewhat lower frequency of PIK3CA mutation in endometrial cancer (10\%) (Miyake et al. 2008). 
In contrast to the data with PTEN, mutations in PIK3CA do appear to be mutually exclusive with mutations of K-Ras in endometrial cancer (Kang et al. 2008; Velasco et al. 2006). However, it is worth noting that this reported mutual exclusivity with oncogenic K-Ras is somewhat controversial (Ollikainen et al. 2007).

Catasus has demonstrated that the presence of PIK3CA mutations is correlated with various clinicopathological factors such as invasion of the myometrium, high grade tumors, deeply invasive tumors that exhibit lymphovascular invasion (Catasus et al. 2008). Most recently, PIK3CA mutations have also been demonstrated in $15 \%$ of uterine serous carcinoma, a less common form of endometrial cancer (Hayes et al. 2009).

\section{Brain tumors}

In the initial report, Samuels et al. sequenced PIK3CA in 15 glioblastoma multiformes (GBMs) and identified four mutations, a 27\% mutation frequency. This was particularly exciting to brain tumor researchers since it implicated PI3K activation in the majority of malignant gliomas, as PTEN was already known to be mutated in a substantial fraction of malignant gliomas. This report was immediately followed up by Broderick et al. who sequenced the catalytic and helical domain of PIK3CA in a large number of different brain tumor types and identified mutations in $14 \%$ of anaplastic oligodendrogliomas, $5 \%$ of GBMs, $5 \%$ of medulloblastomas, and 3\% of anaplastic astrocytomas. No mutations were identified in low grade astrocytomas or ependymomas (Broderick et al. 2004).

Hartman et al., Knobbe et al., and Kita et al., also sequenced PIK3CA in GBMs and all reported a mutation rate of $\sim 5 \%$ (Hartmann et al. 2005; Kita et al. 2007; Knobbe et al. 2005). Gallia et al. identified mutations of PIK3CA in $15 \%$ of GBMs, and demonstrated that the frequency of mutation was roughly equivalent among cell lines, xenografts, and primary tumors (Gallia et al. 2006). They further demonstrated an equivalent frequency of mutation between pediatric and adult GBMs. Hartmann et al. have sequenced PIK3CA in oligodendrogliomas and identified a mutation frequency of $\sim 2 \%$ (Hartmann et al. 2006).

In contrast, Mueller et al. sequenced PIK3CA in 30 primary GBMs but were unable to identify any mutations (Mueller et al. 2005), and suggested that PIK3CA mutations could be more common in GBM cell lines than in primary GBMs. However, this group studied a relatively small number of samples that were intentionally biased toward samples with wildtype PTEN genes. In light of subsequent studies in endometrial cancer demonstrating that PIK3CA mutations can actually occur preferentially in tumors with mutant PTEN genes, it is possible that the sample set used by these investigators could have led to a reduced apparent frequency of PIK3CA mutations in GBM. Finally, Pang et al. have sequenced PIK3CA in meningiomas and identified a low mutation frequency of $1 \%$ (Pang et al. 2006).

\section{Skin cancer}

Perhaps one of the most interesting and surprising recent findings in the PIK3CA field was the recent report of common hotspot mutations of PIK3CA in two benign skin lesions epidermal nevi and seborrheic keratoses (SK), two noninvasive keratinocyte-derived skin tumors. Epidermal nevi are congenital lesions that are either present at birth or develop during early childhood, whereras SK are similar lesions that are associated with the aging process. Hafner et al. sequenced the hotspot exons of PIK3CA in these tumors and demonstrated that $27 \%$ of EN and 16\% of SK harbor PIK3CA mutations (Hafner et al. 2007, 2008), and further demonstrated that PIK3CA mutations are present in solar lentigo, thought to be a precursor lesion for SK (Hafner et al. 2009). These intriguing findings challenge the idea that PIK3CA mutations are associated with tumor cell invasion (Samuels et al. 2004). Additionally, they are reminiscent of previous findings in colon cancer demonstrating that if 
K-Ras mutations occur in the early stages of tumorigenesis, they lead to the formation of a benign lesion known as an aberrant crypt focus instead of frank cancer (Jen et al. 1994). The finding of PIK3CA mutations in these benign skin tumors also raises the possibility that mutational activation of PIK3CA may be causing oncogene-induced senescence in human keratinocytes, as mutational activation of PIK3CA genes has been shown to lead to senescent-like features in several human cell types (Kim et al. 2007).

In contrast to the frequent mutations of PIK3CA in these benign skin tumors, mutations of PIK3CA are relatively rare in malignant melanoma $(\sim 3 \%)$, which was surprising given the prominent role of PTEN inactivation in this tumor type (Omholt et al. 2006).

\section{Ovarian cancer}

Even before the identification of PIK3CA mutations, it was widely appreciated that amplification and overexpression of PIK3CA was found in a substantial number of ovarian cancers (Shayesteh et al. 1999; Zhang et al. 2003). As such, after the initial report of PIK3CA mutations, several groups immediately sequenced the gene in ovarian cancer and identified a mutation frequency of 4-12\% (Campbell et al. 2004; Levine et al. 2005; Wang et al. 2005). Campbell et al. and Wang et al. also clearly demonstrated a substantial histological subtype bias, in that mutations were much more common in the relatively rare endometrioid, clear cell, and mucinous types; whereas they were fairly rare in the most common serous type tumors. The fact that these mutations were rare in serous tumors was also confirmed by Nakayama et al. (2006). Most recently, Kolasa et al. demonstrated that mutant PIK3CA correlates with low FIGO stage, lower tumor grade, and early age at diagnosis (Kolasa et al. 2009).

\section{Gastric cancer}

Even before the work of Samuels et al. PIK3CA had been implicated in the pathogenesis of gastric cancer by the identification of genomic amplifications (Byun et al. 2003). Then, in their initial study, Samuels et al. identified PIK3CA mutations in 25\% gastric cancers (3/12) (Samuels et al. 2004). Subsequent studies reported somewhat lower mutation frequencies of 4 and 11\% (Li et al. 2005; Velho et al. 2005). However, little additional work has been performed on clinicopathological correlates of PIK3CA in this tumor type.

\section{Lung cancer}

Amplifications of PIK3CA in lung cancer were reported by Massion et al. (2004). That same year, Samuels et al. reported a low (4\%) frequency of PIK3CA mutations in lung cancer (Samuels et al. 2004). Kawano et al. then confirmed this low frequency in a larger sample set (Kawano et al. 2006). Of note, they demonstrated that PIK3CA mutation occurs more commonly in squamous cell carcinoma (7\%) than in adenocarcinoma (2\%). Okudela et al. similarly identified mutations of PIK3CA in 4\% of lung cancers (Okudela et al. 2007). Finally, in the largest lung cancer study performed to date, Yamamoto et al. studied $>700$ lung cancer samples and identified PIK3CA mutations in $2 \%$ of all major histology types (Yamamoto et al. 2008).

Interestingly, Kawano et al. were the first (and as yet only) to demonstrate that mutant alleles of PIK3CA are occasionally amplified in cancer cells (Kawano et al. 2007). This finding is strikingly reminiscent of the well-described amplification of mutant alleles of EGFR that also occurs in lung cancer (Sharma et al. 2007).

\section{Thyroid cancer}

There is some disagreement in the literature regarding the role of PIK3CA mutation in the pathogenesis of thyroid cancer, perhaps in part due to the wide variety of different 
pathological types of this disease. However, when taken together, the studies suggest that PIK3CA mutations are more important in the pathogenesis of anaplastic thyroid cancer and follicular thyroid cancer than in the pathogenesis of papillary carcinoma of the thyroid.

In the initial, very large study, Garcia-Rostan identified PIK3CA mutations in $16 \%$ of anaplastic thyroid carcinomas, $8 \%$ of follicular thyroid carcinomas, and $2 \%$ of papillary thyroid carcinomas (Garcia-Rostan et al. 2005). However, that same year Wu et al. suggested that PIK3CA mutations rarely occurred in these tumor types (Wu et al. 2005a). In a subsequent study, Wang et al. reported PIK3CA mutations in 13\% of follicular thyroid carcinomas and $1 \%$ of papillary thyroid carcinomas (Wang et al. 2007). Abubaker et al. then specifically focused on papillary thyroid carcinoma and identified mutations in $2 \%$ of 499 cases studied (Abubaker et al. 2008b). Similarly, Santarpia et al. focused exclusively on anaplastic thyroid cancer and identified mutations in $14 \%$ of 36 cases (Santarpia et al. 2008).

\section{Head and neck cancer}

A large number of studies have examined the role of PIK3CA mutation in the pathogenesis of head and neck cancer. Qiu et al. evaluated PIK3CA mutational status in 38 squamous cell carcinomas and identified four samples with mutations (11\%). Interestingly, in three of the four cases with mutations were derived from pharyngeal cancer samples (Qiu et al. 2006). Later, this group used a more sensitive mutation detection method that made it possible to identify mutations in tumors of mixed origin and found the mutation rate to be significantly higher than previously reported (21\%) (Qiu et al. 2008). Kozaki et al. sequenced PIK3CA in oral squamous cell carcinomas and identified mutations in $21 \%$ of cell lines and $17 \%$ of primary tumors (Kozaki et al. 2006). Yan Yan et al. were unable to identify mutations of PIK3CA in pharyngeal cancer samples (Or et al. 2006). Liu et al. identified mutations of PIK3CA in $4 \%$ of nasopharyngeal carcinomas (Liu et al. 2007). Fenic et al. were unable to identify any mutations of PIK3CA in a series of 33 squamous cell carcinomas (Fenic et al. 2007). Chou et al. identified PIK3CA mutations in 10\% of nasopharyngeal carcinomas, and demonstrated that there was no significant relationship to clinicopathological characteristics of the tumors (Chou et al. 2008). Murugan et al. identified mutations in 30\% of head and neck cancer cell lines, $11 \%$ in primary tumors from patients in India, and no tumors from Vietnam (Murugan et al. 2008).

\section{Cervical cancer}

It was appreciated that amplification and overexpression of PIK3CA played an important role in the pathogenesis of cervical cancer, even before the identification of PIK3CA mutations (Ma et al. 2000). Then, Miyake et al. identified mutations of PIK3CA in 3 of 22 cases (14\%) (Miyake et al. 2008) and Cui et al. identified mutations in 15/184 invasive cervical carcinomas (8\%) (Cui et al. 2009).

\section{Pancreatic cancer}

Schonleben et al. identified PIK3CA in 11\% of intraductal papillary mucinous carcinoma of the pancreas (Schonleben et al. 2006).

\section{Esophageal cancer}

Phillips et al. identified PIK3CA mutations in $12 \%$ of squamous cell carcinomas of the esophagus, and 6\% of adenocarcinomas of the esophagus (Phillips et al. 2006). Mori et al. identified mutations in 2/88 (2\%) of esophageal squamous cell carcinomas (Mori et al. 2008). In contrast, Akagi et al. did not identify any PIK3CA mutations in esophageal squamous cell carcinoma (Akagi et al. 2009). 


\section{Liver/biliary tract cancer}

Riener et al. evaluated both liver and biliary tract tumors for PIK3CA mutations and identified mutations in $1 / 45$ cholangiocarcinomas (2\%), 1/23 gallbladder carcinomas (4\%), and 1/50 hepatocellular carcinomas (2\%) (Riener et al. 2008). Tanaka et al. were unable to identify any mutations of PIK3CA in 47 hepatocellular cancers from Japanese patients (Tanaka et al. 2006).

\section{Pituitary tumors}

Lin et. evaluated 353 pituitary tumors and identified PIK3CA mutations in 8/91 invasive pituitary tumors (9\%) but not in any of 262 noninvasive pituitary tumors (Lin et al. 2009). Of note, these data are consistent with the idea initially expressed by Samuels et al. that mutation of PIK3CA correlates with invasiveness.

\section{Urological tumors}

Andersson et al. identified mutations of PIK3CA in 8/28 penile tumors (29\%) (Andersson et al. 2008). Lopez-Knowles identified PIK3CA mutations in 11/87 (13\%) of bladder cancers (Lopez-Knowles et al. 2006).

\section{Leukemia/lymphoma}

PIK3CA mutations were identified in 17/215 diffuse large B cell lymphomas (Abubaker et al. 2007). Muller et al. did not identify any mutations of PIK3CA in acute myeloid leukemia, myelodysplastic syndromes, or non-Hodgkin lymphomas (Muller et al. 2007). Similarly, Hummerdal wa unable to identify PIK3CA in acute myeloid leukemia (Hummerdal et al. 2006).

\section{Neuroblastoma}

Dam et al. were unable to identify PIK3CA mutations in any of 69 neuroblastomas (Dam et al. 2006).

These mutation frequencies indicate that PIK3CA is one of the two most commonly mutated genes identified in human cancers (the other being KRAS). Taken together, the genetic alterations described above suggested that mutant PIK3CA is an oncogene for the following reasons: (a) the high mutation frequency, (b) the vast majority of mutations are heterozygous missense changes, (c) many of the mutations affect highly conserved residues, and (d) more than $80 \%$ of the mutations in PIK3CA cluster in two regions, within the helical (exon 9) and catalytic (exon 20) domains. These characteristics suggested that these genetic alterations may be kinase activating, similar to oncogenic mutations found in other oncogenes such as BRAF (Davies et al. 2002; Rajagopalan et al. 2002). Indeed, follow-up functional analyses of the PIK3CA mutations confirmed them to be constitutively kinase activating and oncogenic (Bader et al. 2006; Kang et al. 2005; Samuels et al. 2004, 2005; Zhao and Vogt 2008).

\section{Somatic Mutations in the PI3K Pathway Typically Occur in a Mutually Exclusive Fashion}

The significance of the PI3K pathway in human cancer was further emphasized by additional mutational analyses of other genes involved in PI3K signaling. If two genes are mutated in a mutually exclusive fashion in a single tumor type, it is likely that they provide the same selective pressure for clonal expansion. This concept has been demonstrated by the mutual exclusivity found between APC and beta-catenin mutations (Morin et al. 1997; Sparks et al. 1998) or KRAS and BRAF mutations (Davies et al. 2002; Rajagopalan et al. 
2002). The work of Saal et al. indicates that this notion is also true for the PI3K pathway (Saal et al. 2005). In this study, the PIK3CA mutation status of a panel of breast tumors which had lost PTEN expression was compared with a matched control set that had retained PTEN expression. A highly significant association between PIK3CA mutations and retention of wild-type PTEN protein expression was observed. However, conflicting data on this point has also been published (Saal et al. 2007).

Another genetic study aimed at testing the involvement of additional members of the PI3K pathway in colorectal cancer evaluated 146 colorectal cancers for somatic mutations in this pathway. Somatic mutations were identified in PDK1 (3/146), p21-activated kinase 4 (PAK4) (2/146), AKT2 (2/146), insulin-related receptor INSRR (1/146), v-Erb-B erythroblastic leukemia viral oncogene homolog ERBB4 (1/146), PTEN (7/146), as well as amplification of the insulin receptor substrate IRS2 (3/146). When these same tumor panel was analyzed for PIK3CA mutations, 37 mutations were found. Thus, a total of 58 alterations were found in the PI3K pathway, yet only two of the tumors had alterations in two genes in the PI3K pathway, making this mutual exclusivity statistically significant ( $\mathrm{p}<$ 0.02, chi-square test) (Parsons et al. 2005).

Similarly, AKT1 was found to be somatically mutated in $8 \%$ breast, $6 \%$ colorectal and $2 \%$ ovarian cancers (Carpten et al. 2007). The AKT1 mutation was found to be mutually exclusive of PIK3CA and complete loss of PTEN protein expression. Although the sample size was insufficient to document statistical significance, the lack of coincidence of these mutations indicates that the AKT1 mutation was sufficient for pathological activation of the PI3K/AKT pathway (Carpten et al. 2007). A similar study by Bleeker et al. showed that AKT1 was mutated in 5\% breast $1.1 \%$ colorectal and $0.6 \%$ lung cancers. Within the neoplasms of breast origin, the AKT1 mutation was mutually exclusive with respect to the PIK3CA mutations (Bleeker et al. 2008).

Strikingly, whole exome sequencing studies (Parsons et al. 2008; Wood et al. 2007) have also highlighted the importance of the PI3K pathway in cancer, as a large portion of the genes found to be somatically mutated are involved in PI3K signaling. In the breast cancer study, these genes included PIK3CA and previously unreported mutations in PIK3R1, PIK3R4, and RPS6KA3. In colorectal cancer the PI3K pathway components found to be mutated differed from those in breast, with mutations found in IRS2, IRS4, PIK3R5, PRKCZ, PTEN, RHEB, and RPS6KB1 in addition to PIK3CA (Wood et al. 2007). Similarly, in the whole genome study of glioblastoma tumors the PI3K genes PIK3CA, PIK3R1, PTEN, and IRS1 were found to be altered in $50 \%$ of tumors and in all cases, mutations within each tumor affected only a single member of the pathway in a mutually exclusive manner $(p<0.05)$ (Parsons et al. 2008). The fact that all but one of the cancers with mutations in members of the PI3K pathway did not have alterations in other members of the same pathway again suggests that such alterations are functionally equivalent in tumorigenesis.

However, as described in greater detail above, similar analyses of endometrial cancer presented a different suggestion. As PTEN mutations occur at high frequency in endometrial carcinoma, primary endometrial carcinomas were screened for mutations in the helical and catalytic domains of PIK3CA and 36\% of tumors had mutations in this gene and coexistence of PIK3CA/PTEN mutations were observed at high frequency (26\%). Interestingly, PIK3CA mutations were more common in tumors with PTEN mutations (46\%) compared with those without PTEN mutations (24\%). Thus, a combination of PIK3CA/PTEN alterations might play a role in development of certain tumors (Oda et al. 2005). 
The emphasis of the importance of the PI3K pathway in cancer development fits with the conclusions of recent mutation analyses in colorectal, breast, pancreatic and glioblastoma cancers that have revealed two unifying features: (1) there are a few major gene alterations that occur in the majority of cancers and a much larger number of genes that are mutated at relatively low frequency. (2) While the number of cancer causing genes has become larger and each cancer type has specific genomic alterations, the altered genes affect a limited number of cellular signaling pathways (Cancer Genome Atlas Research Network 2008; Jones et al. 2008; Parsons et al. 2008; Sjoblom et al. 2006; Wood et al. 2007).

In the case of colon cancer, it appears that the molecular explanation for activation of PI3K signaling is generally now understood. However, there are many other tumor types in which the gene causing PI3K activation has not yet been discovered. For example, several studies have indicated that approximately sixty percent of melanomas contain activated AKT (most likely the Akt3 isoform) (Stahl et al. 2004; Bastian et al. 1998). There are several known genetic events that explain a subset of these cases. For example, somatic inactivation of PTEN is found in 10-30\% of melanomas (Birck et al. 2000; Chudnovsky et al. 2005; Guldberg et al. 1997; Robertson et al. 1998; Tsao et al. 1998; Zhou et al. 2000), and mutational activation of PIK3CA is found in another 3\% (Board et al. 2008; Omholt et al. 2006). Amplification of the Akt 3 locus itself is also likely to be responsible for an additional small fraction of cases with Akt activation (Bastian et al. 1998; Thompson et al. 1995). However, this leaves $>20 \%$ of melanoma cases with unexplained activation of Akt. As such, it is likely that one or more other members of the PI3K pathway suffer somatic mutations in this disease process and are responsible for AKT activation in the remaining tumors. A mutational analysis of additional genes that lie in these two pathways may identify novel somatic mutations in melanoma.

These types of additional sequencing studies are particularly exciting since they have the potential to uncover additional mutations affecting the PI3K pathway and provide a strong rationale for development of new therapeutic and diagnostic approaches for the already sizable number of individuals who have mutations in the PI3K pathway.

In addition to providing substantial insight into the basic biological mechanisms that drive human cancer pathogenesis, the discovery of activating mutations in PIK3CA has caused academic and industrial groups to redouble their efforts to develop and test pharmacological inhibitors of PI3K, since mutations in the PI3K signaling pathway are now known to occur at a frequency double what was previously predicted. Numerous academic and industrial groups are currently developing and testing novel pharmacological inhibitors of PI3K enzymes, and this is discussed in much detail in other sections of this book. However, the discovery of oncogenic mutations in PIK3CA itself has provided substantial impetus to these efforts since it has dramatically emphasized the important role of PI3K in cancer pathogenesis and made it possible to quickly and easily identify tumors with activation of PI3K signaling by virtue of mutations in PIK3CA.

\section{Conclusion}

By combining the large amount of sequencing data over the past 5 years, we find that PIK3CA is one of the most commonly mutated oncogenes in human cancers. In all the tumor types examined to date, mutations cluster within two hotspots. It is now evident that cancers of the endometrium, breast, and colon, as well as benign tumors of the skin are among the tumor types with the highest frequencies of PIK3CA mutations. There is some inconsistency in the literature regarding the frequency of PIK3CA mutations in individual tumor types; however, these discrepancies are likely due to a number of factors including the specific exons that were sequenced, geographical variation, sample source preservation and 
methods used for DNA isolation. However, despite these discrepancies, the high frequency of PIK3CA mutation and the discovery of hotspot mutations have important clinical implications for diagnosis, prognosis and therapy. Targeting this mutant protein with novel therapeutics could have a substantial impact on eliminating the morbidity and mortality of human cancer.

\section{References}

Abubaker J, Bavi PP, Al-Harbi S, Siraj AK, Al-Dayel F, Uddin S, Al-Kuraya K. PIK3CA mutations are mutually exclusive with PTEN loss in diffuse large B-cell lymphoma. Leukemia. 2007; 21:2368-2370. [PubMed: 17657213]

Abubaker J, Bavi P, Al-Harbi S, Ibrahim M, Siraj AK, Al-Sanea N, Abduljabbar A, Ashari LH, Alhomoud S, Al-Dayel F, et al. Clinicopathological analysis of colorectal cancers with PIK3CA mutations in Middle Eastern population. Oncogene. 2008a; 27:3539-3545. [PubMed: 18193083]

Abubaker J, Jehan Z, Bavi P, Sultana M, Al-Harbi S, Ibrahim M, Al-Nuaim A, Ahmed M, Amin T, Al-Fehaily M, et al. Clinicopathological analysis of papillary thyroid cancer with PIK3CA alterations in a Middle Eastern population. J Clin Endocrinol Metab. 2008b; 93:611-618. [PubMed: 18000091]

Actor B, Cobbers JM, Buschges R, Wolter M, Knobbe CB, Lichter P, Reifenberger G, Weber RG. Comprehensive analysis of genomic alterations in gliosarcoma and its two tissue components. Genes Chromosomes Cancer. 2002; 34:416-427. [PubMed: 12112531]

Akagi I, Miyashita M, Makino H, Nomura T, Hagiwara N, Takahashi K, Cho K, Mishima T, Ishibashi $\mathrm{O}$, Ushijima T, et al. Overexpression of PIK3CA is associated with lymph node metastasis in esophageal squamous cell carcinoma. Int J Oncol. 2009; 34:767-775. [PubMed: 19212681]

Andersson P, Kolaric A, Windahl T, Kirrander P, Soderkvist P, Karlsson MG. PIK3CA, HRAS and KRAS gene mutations in human penile cancer. J Urol. 2008; 179:2030-2034. [PubMed: 18355852]

Bachman KE, Argani P, Samuels Y, Silliman N, Ptak J, Szabo S, Konishi H, Karakas B, Blair BG, Lin $\mathrm{C}$, et al. The PIK3CA gene is mutated with high frequency in human breast cancers. Cancer Biol Ther. 2004; 3:772-775. [PubMed: 15254419]

Bader AG, Kang S, Vogt PK. Cancer-specific mutations in PIK3CA are oncogenic in vivo. Proc Natl Acad Sci USA. 2006; 103:1475-1479. [PubMed: 16432179]

Barault L, Veyrie N, Jooste V, Lecorre D, Chapusot C, Ferraz JM, Lievre A, Cortet M, Bouvier AM, Rat $\mathrm{P}$, et al. Mutations in the RAS-MAPK, PI(3)K (phosphatidylinositol-3-OH kinase) signaling network correlate with poor survival in a population-based series of colon cancers. Int J Cancer. 2008; 122:2255-2259. [PubMed: 18224685]

Barbareschi M, Buttitta F, Felicioni L, Cotrupi S, Barassi F, Del Grammastro M, Ferro A, Dalla Palma P, Galligioni E, Marchetti A. Different prognostic roles of mutations in the helical and kinase domains of the PIK3CA gene in breast carcinomas. Clin Cancer Res. 2007; 13:6064-6069. [PubMed: 17947469]

Bardelli A, Parsons DW, Silliman N, Ptak J, Szabo S, Saha S, Markowitz S, Willson JK, Parmigiani G, Kinzler KW, et al. Mutational analysis of the tyrosine kinome in colorectal cancers. Science. 2003; 300:949. [PubMed: 12738854]

Barr FG, Galili N, Holick J, Biegel JA, Rovera G, Emanuel BS. Rearrangement of the PAX3 paired box gene in the paediatric solid tumour alveolar rhabdomyosarcoma. Nat Genet. 1993; 3:113-117. [PubMed: 8098985]

Bastian BC, LeBoit PE, Hamm H, Brocker EB, Pinkel D. Chromosomal gains and losses in primary cutaneous melanomas detected by comparative genomic hybridization. Cancer Res. 1998; 58:2170-2175. [PubMed: 9605762]

Bellacosa A, Testa JR, Staal SP, Tsichlis PN. A retroviral oncogene, akt, encoding a serine-threonine kinase containing an SH2-like region. Science. 1991; 254:274-277. [PubMed: 1833819]

Bellacosa A, de Feo D, Godwin AK, Bell DW, Cheng JQ, Altomare DA, Wan M, Dubeau L, Scambia G, Masciullo V, et al. Molecular alterations of the AKT2 oncogene in ovarian and breast carcinomas. Int J Cancer. 1995; 64:280-285. [PubMed: 7657393]

Curr Top Microbiol Immunol. Author manuscript; available in PMC 2011 August 31. 
Benvenuti S, Frattini M, Arena S, Zanon C, Cappelletti V, Coradini D, Daidone MG, Pilotti S, Pierotti MA, Bardelli A. PIK3CA cancer mutations display gender and tissue specificity patterns. Hum Mutat. 2008; 29:284-288. [PubMed: 18022911]

Berns K, Horlings HM, Hennessy BT, Madiredjo M, Hijmans EM, Beelen K, Linn SC, GonzalezAngulo AM, Stemke-Hale K, Hauptmann M, et al. A functional genetic approach identifies the $\mathrm{PI} 3 \mathrm{~K}$ pathway as a major determinant of trastuzumab resistance in breast cancer. Cancer Cell. 2007; 12:395-402. [PubMed: 17936563]

Birck A, Ahrenkiel V, Zeuthen J, Hou-Jensen K, Guldberg P. Mutation and allelic loss of the PTEN/ MMAC1 gene in primary and metastatic melanoma biopsies. J Invest Dermatol. 2000; 114:277280. [PubMed: 10651986]

Bleeker FE, Felicioni L, Buttitta F, Lamba S, Cardone L, Rodolfo M, Scarpa A, Leenstra S, Frattini M, Barbareschi M, et al. AKT1(E17K) in human solid tumours. Oncogene. 2008; 27:5648-5650. [PubMed: 18504432]

Board RE, Thelwell NJ, Ravetto PF, Little S, Ranson M, Dive C, Hughes A, Whitcombe D. Multiplexed assays for detection of mutations in PIK3CA. Clin Chem. 2008; 54:757-760. [PubMed: 18375489]

Bos JL, Fearon ER, Hamilton SR, Verlaan-de Vries M, van Boom JH, van der Eb AJ, Vogelstein B. Prevalence of ras gene mutations in human colorectal cancers. Nature. 1987; 327:293-297. [PubMed: 3587348]

Broderick DK, Di C, Parrett TJ, Samuels YR, Cummins JM, McLendon RE, Fults DW, Velculescu VE, Bigner DD, Yan H. Mutations of PIK3CA in anaplastic oligodendrogliomas, high-grade astrocytomas, and medulloblastomas. Cancer Res. 2004; 64:5048-5050. [PubMed: 15289301]

Buttitta F, Felicioni L, Barassi F, Martella C, Paolizzi D, Fresu G, Salvatore S, Cuccurullo F, Mezzetti A, Campani D, Marchetti A. PIK3CA mutation and histological type in breast carcinoma: high frequency of mutations in lobular carcinoma. J Pathol. 2006; 208:350-355. [PubMed: 16353168]

Byun DS, Cho K, Ryu BK, Lee MG, Park JI, Chae KS, Kim HJ, Chi SG. Frequent monoallelic deletion of PTEN and its reciprocal associatioin with PIK3CA amplification in gastric carcinoma. Int J Cancer. 2003; 104:318-327. [PubMed: 12569555]

Campbell IG, Russell SE, Choong DY, Montgomery KG, Ciavarella ML, Hooi CS, Cristiano BE, Pearson RB, Phillips WA. Mutation of the PIK3CA gene in ovarian and breast cancer. Cancer Res. 2004; 64:7678-7681. [PubMed: 15520168]

Cancer Genome Atlas Research Network. Comprehensive genomic characterization defines human glioblastoma genes and core pathways. Nature. 2008; 455:1061-1068. [PubMed: 18772890]

Cantley LC. The phosphoinositide 3-kinase pathway. Science. 2002; 296:1655-1657. [PubMed: 12040186]

Cantley LC, Auger KR, Carpenter C, Duckworth B, Graziani A, Kapeller R, Soltoff S. Oncogenes and signal transduction. Cell. 1991; 64:281-302. [PubMed: 1846320]

Carpten JD, Faber AL, Horn C, Donoho GP, Briggs SL, Robbins CM, Hostetter G, Boguslawski S, Moses TY, Savage S, et al. A transforming mutation in the pleckstrin homology domain of AKT1 in cancer. Nature. 2007; 448:439-444. [PubMed: 17611497]

Catasus L, Gallardo A, Cuatrecasas M, Prat J. PIK3CA mutations in the kinase domain (exon 20) of uterine endometrial adenocarcinomas are associated with adverse prognostic parameters. Mod Pathol. 2008; 21:131-139. [PubMed: 18084252]

Chang HW, Aoki M, Fruman D, Auger KR, Bellacosa A, Tsichlis PN, Cantley LC, Roberts TM, Vogt PK. Transformation of chicken cells by the gene encoding the catalytic subunit of PI 3-kinase. Science. 1997; 276:1848-1850. [PubMed: 9188528]

Chen Z, Trotman LC, Shaffer D, Lin HK, Dotan ZA, Niki M, Koutcher JA, Scher HI, Ludwig T, Gerald W, et al. Crucial role of p53-dependent cellular senescence in suppression of Pten-deficient tumorigenesis. Nature. 2005; 436:725-730. [PubMed: 16079851]

Cheng JQ, Godwin AK, Bellacosa A, Taguchi T, Franke TF, Hamilton TC, Tsichlis PN, Testa JR. AKT2, a putative oncogene encoding a member of a subfamily of protein-serine/ threonine kinases, is amplified in human ovarian carcinomas. Proc Natl Acad Sci USA. 1992; 89:92679271. [PubMed: 1409633] 
Cheng JQ, Ruggeri B, Klein WM, Sonoda G, Altomare DA, Watson DK, Testa JR. Amplification of AKT2 in human pancreatic cells and inhibition of AKT2 expression and tumorigenicity by antisense RNA. Proc Natl Acad Sci USA. 1996; 93:3636-3641. [PubMed: 8622988]

Chou CC, Chou MJ, Tzen CY. PIK3CA mutation occurs in nasopharyngeal carcinoma but does not significantly influence the disease-specific survival. Med Oncol. 2008; 26(3):322-326. [PubMed: 19012001]

Chudnovsky Y, Khavari PA, Adams AE. Melanoma genetics and the development of rational therapeutics. J Clin Invest. 2005; 115:813-824. [PubMed: 15841168]

Cui B, Zheng B, Zhang X, Stendahl U, Andersson S, Wallin KL. Mutation of PIK3CA: possible risk factor for cervical carcinogenesis in older women. Int J Oncol. 2009; 34:409-416. [PubMed: 19148475]

Dam V, Morgan BT, Mazanek P, Hogarty MD. Mutations in PIK3CA are infrequent in neuroblastoma. BMC Cancer. 2006; 6:177. [PubMed: 16822308]

Davies H, Bignell GR, Cox C, Stephens P, Edkins S, Clegg S, Teague J, Woffendin H, Garnett MJ, Bottomley W, et al. Mutations of the BRAF gene in human cancer. Nature. 2002; 417(6892):949954. [PubMed: 12068308]

Eichhorn PJ, Gili M, Scaltriti M, Serra V, Guzman M, Nijkamp W, Beijersbergen RL, Valero V, Seoane J, Bernards R, Baselga J. Phosphatidylinositol 3-kinase hyperactivation results in lapatinib resistance that is reversed by the mTOR/phosphatidylinositol 3-kinase inhibitor NVP-BEZ235. Cancer Res. 2008; 68:9221-9230. [PubMed: 19010894]

Fenic I, Steger K, Gruber C, Arens C, Woenckhaus J. Analysis of PIK3CA and Akt/protein kinase B in head and neck squamous cell carcinoma. Oncol Rep. 2007; 18:253-259. [PubMed: 17549376]

Gallia GL, Rand V, Siu IM, Eberhart CG, James CD, Marie SK, Oba-Shinjo SM, Carlotti CG, Caballero OL, Simpson AJ, et al. PIK3CA gene mutations in pediatric and adult glioblastoma multiforme. Mol Cancer Res. 2006; 4:709-714. [PubMed: 17050665]

Garcia-Rostan G, Costa AM, Pereira-Castro I, Salvatore G, Hernandez R, Hermsem MJ, Herrero A, Fusco A, Cameselle-Teijeiro J, Santoro M. Mutation of the PIK3CA gene in anaplastic thyroid cancer. Cancer Res. 2005; 65:10199-10207. [PubMed: 16288007]

Guldberg P, thor Straten P, Birck A, Ahrenkiel V, Kirkin AF, Zeuthen J. Disruption of the MMAC1/ PTEN gene by deletion or mutation is a frequent event in malignant melanoma. Cancer Res. 1997; 57:3660-3663. [PubMed: 9288767]

Hafner C, Lopez-Knowles E, Luis NM, Toll A, Baselga E, Fernandez-Casado A, Hernandez S, Ribe A, Mentzel T, Stoehr R, et al. Oncogenic PIK3CA mutations occur in epidermal nevi and seborrheic keratoses with a characteristic mutation pattern. Proc Natl Acad Sci USA. 2007; 104:13450-13454. [PubMed: 17673550]

Hafner C, Vogt T, Landthaler M, Musebeck J. Somatic FGFR3 and PIK3CA mutations are present in familial seborrhoeic keratoses. Br J Dermatol. 2008; 159:214-217. [PubMed: 18503601]

Hafner C, Stoehr R, van Oers JM, Zwarthoff EC, Hofstaedter F, Landthaler M, Hartmann A, Vogt T. FGFR3 and PIK3CA mutations are involved in the molecular pathogenesis of solar lentigo. $\mathrm{Br} \mathrm{J}$ Dermatol. 2009; 160:546-551. [PubMed: 19076977]

Hartmann C, Bartels G, Gehlhaar C, Holtkamp N, von Deimling A. PIK3CA mutations in glioblastoma multiforme. Acta Neuropathol. 2005; 109:639-642. [PubMed: 15924253]

Hartmann C, Devermann L, Gehlhaar C, Holtkamp N, von Deimling A. PIK3CA mutations in oligodendroglial tumours. Neuropathol Appl Neurobiol. 2006; 32:209-212. [PubMed: 16599949]

Hayes MP, Wang H, Espinal-Witter R, Douglas W, Solomon GJ, Baker SJ, Ellenson LH. PIK3CA and PTEN mutations in uterine endometrioid carcinoma and complex atypical hyperplasia. Clin Cancer Res. 2006; 12:5932-5935. [PubMed: 17062663]

Hayes MP, Douglas W, Ellenson LH. Molecular alterations of EGFR and PIK3CA in uterine serous carcinoma. Gynecol Oncol. 2009; 113(3):370-373. [PubMed: 19272638]

Hummerdal P, Andersson P, Willander K, Linderholm M, Soderkvist P, Jonsson JI. Absence of hot spot mutations of the PIK3CA gene in acute myeloid leukaemia. Eur J Haematol. 2006; 77:86-87. [PubMed: 16573740] 
Jen J, Powell SM, Papadopoulos N, Smith KJ, Hamilton SR, Vogelstein B, Kinzler KW. Molecular determinants of dysplasia in colorectal lesions. Cancer Res. 1994; 54:5523-5526. [PubMed: 7923189]

Jhawer M, Goel S, Wilson AJ, Montagna C, Ling YH, Byun DS, Nasser S, Arango D, Shin J, Klampfer L, et al. PIK3CA mutation/PTEN expression status predicts response of colon cancer cells to the epidermal growth factor receptor inhibitor cetuximab. Cancer Res. 2008; 68:19531961. [PubMed: 18339877]

Jones S, Zhang X, Parsons DW, Lin JC, Leary RJ, Angenendt P, Mankoo P, Carter H, Kamiyama H, Jimeno A, et al. Core signaling pathways in human pancreatic cancers revealed by global genomic analyses. Science. 2008; 321:1801-1806. [PubMed: 18772397]

Kang S, Bader AG, Vogt PK. Phosphatidylinositol 3-kinase mutations identified in human cancer are oncogenic. Proc Natl Acad Sci USA. 2005; 102:802-807. [PubMed: 15647370]

Kang S, Seo SS, Chang HJ, Yoo CW, Park SY, Dong SM. Mutual exclusiveness between PIK3CA and KRAS mutations in endometrial carcinoma. Int J Gynecol Cancer. 2008; 18:1339-1343. [PubMed: 18221484]

Kato S, Iida S, Higuchi T, Ishikawa T, Takagi Y, Yasuno M, Enomoto M, Uetake H, Sugihara K. PIK3CA mutation is predictive of poor survival in patients with colorectal cancer. Int J Cancer. 2007; 121:1771-1778. [PubMed: 17590872]

Katso R, Okkenhaug K, Ahmadi K, White S, Timms J, Waterfield MD. Cellular function of phosphoinositide 3-kinases: implications for development, homeostasis, and cancer. Annu Rev Cell Dev Biol. 2001; 17:615-675. [PubMed: 11687500]

Kawano O, Sasaki H, Endo K, Suzuki E, Haneda H, Yukiue H, Kobayashi Y, Yano M, Fujii Y. PIK3CA mutation status in Japanese lung cancer patients. Lung Cancer. 2006; 54:209-215. [PubMed: 16930767]

Kawano O, Sasaki H, Okuda K, Yukiue H, Yokoyama T, Yano M, Fujii Y. PIK3CA gene amplification in Japanese non-small cell lung cancer. Lung Cancer. 2007; 58:159-160. [PubMed: 17681398]

Kim JS, Lee C, Bonifant CL, Ressom H, Waldman T. Activation of p53-dependent growth suppression in human cells by mutations in PTEN or PIK3CA. Mol Cell Biol. 2007; 27:662-677. [PubMed: 17060456]

Kita D, Yonekawa Y, Weller M, Ohgaki H. PIK3CA alterations in primary (de novo) and secondary glioblastomas. Acta Neuropathol. 2007; 113:295-302. [PubMed: 17235514]

Knobbe CB, Reifenberger G. Genetic alterations and aberrant expression of genes related to the phosphatidyl-inositol-3'-kinase/protein kinase B (Akt) signal transduction pathway in glioblastomas. Brain Pathol. 2003; 13:507-518. [PubMed: 14655756]

Knobbe CB, Trampe-Kieslich A, Reifenberger G. Genetic alteration and expression of the phosphoinositol-3-kinase/Akt pathway genes PIK3CA and PIKE in human glioblastomas. Neuropathol Appl Neurobiol. 2005; 31:486-490. [PubMed: 16150119]

Kolasa IK, Rembiszewska A, Felisiak A, Ziolkowska-Seta I, Murawska M, Moes J, Timorek A, Dansonka-Mieszkowska A, Kupryjanczyk J. PIK3CA amplification associates with resistance to chemotherapy in ovarian cancer patients. Cancer Biol Ther. 2009; 8:21-26. [PubMed: 19029838]

Kozaki K, Imoto I, Pimkhaokham A, Hasegawa S, Tsuda H, Omura K, Inazawa J. PIK3CA mutation is an oncogenic aberration at advanced stages of oral squamous cell carcinoma. Cancer Sci. 2006; 97:1351-1358. [PubMed: 17052259]

Lai YL, Mau BL, Cheng WH, Chen HM, Chiu HH, Tzen CY. PIK3CA exon 20 mutation is independently associated with a poor prognosis in breast cancer patients. Ann Surg Oncol. 2008; 15:1064-1069. [PubMed: 18183466]

Lee JW, Soung YH, Kim SY, Lee HW, Park WS, Nam SW, Kim SH, Lee JY, Yoo NJ, Lee SH. PIK3CA gene is frequently mutated in breast carcinomas and hepatocellular carcinomas. Oncogene. 2005; 24:1477-1480. [PubMed: 15608678]

Lerma E, Catasus L, Gallardo A, Peiro G, Alonso C, Aranda I, Barnadas A, Prat J. Exon 20 PIK3CA mutations decreases survival in aggressive (HER-2 positive) breast carcinomas. Virchows Arch. 2008; 453:133-139. [PubMed: 18679714] 
Levine DA, Bogomolniy F, Yee CJ, Lash A, Barakat RR, Borgen PI, Boyd J. Frequent mutation of the PIK3CA gene in ovarian and breast cancers. Clin Cancer Res. 2005; 11:2875-2878. [PubMed: 15837735]

Li J, Yen C, Liaw D, Podsypanina K, Bose S, Wang SI, Puc J, Miliaresis C, Rodgers L, McCombie R, et al. PTEN, a putative protein tyrosine phosphatase gene mutated in human brain, breast, and prostate cancer. Science. 1997; 275:1943-1947. [PubMed: 9072974]

Li VS, Wong CW, Chan TL, Chan AS, Zhao W, Chu KM, So S, Chen X, Yuen ST, Leung SY. Mutations of PIK3CA in gastric adenocarcinoma. BMC Cancer. 2005; 5:29. [PubMed: 15784156]

Li SY, Rong M, Grieu F, Iacopetta B. PIK3CA mutations in breast cancer are associated with poor outcome. Breast Cancer Res Treat. 2006; 96:91-95. [PubMed: 16317585]

Liedtke C, Cardone L, Tordai A, Yan K, Gomez HL, Figureoa LJ, Hubbard RE, Valero V, Souchon EA, Symmans WF, et al. PIK3CA-activating mutations and chemotherapy sensitivity in stage IIIII breast cancer. Breast Cancer Res. 2008; 10:R27. [PubMed: 18371219]

Lin Y, Jiang X, Shen Y, Li M, Ma H, Xing M, Lu Y. Frequent mutations and amplifications of the PIK3CA gene in pituitary tumors. Endocr Relat Cancer. 2009; 16:301-310. [PubMed: 18852163]

Liu P, Li DJ, Qin HD, Zhang RH, Chen LZ, Zeng YX. Screening for mutations in the hotspot mutation regions of PIK3CA gene in nasopharyngeal carcinoma. Ai Zheng. 2007; 26:15-20. [PubMed: 17222361]

Lopez-Knowles E, Hernandez S, Malats N, Kogevinas M, Lloreta J, Carrato A, Tardon A, Serra C, Real FX. PIK3CA mutations are an early genetic alteration associated with FGFR3 mutations in superficial papillary bladder tumors. Cancer Res. 2006; 66:7401-7404. [PubMed: 16885334]

Ma YY, Wei SJ, Lin YC, Lung JC, Chang TC, Whang-Peng J, Liu JM, Yang DM, Yang WK, Shen CY. PIK3CA as an oncogene in cervical cancer. Oncogene. 2000; 19:2739-2744. [PubMed: 10851074]

Maruyama N, Miyoshi Y, Taguchi T, Tamaki Y, Monden M, Noguchi S. Clinicopathologic analysis of breast cancers with PIK3CA mutations in Japanese women. Clin Cancer Res. 2007; 13:408-414. [PubMed: 17202311]

Massion PP, Taflan PM, Shyr Y, Rahman SM, Yildiz P, Shakthour B, Edgerton ME, Ninan M, Andersen JJ, Gonzalez AL. Early involvement of the phosphatidylinositol 3-kinase/Akt pathway in lung cancer progression. Am J Respir Crit Care Med. 2004; 170:1088-1094. [PubMed: 15317667]

Mikami M, Nosho K, Yamamoto H, Takahashi T, Maehata T, Taniguchi H, Adachi Y, Imamura A, Fujita M, Hosokawa M, et al. Mutational analysis of beta-catenin and the RAS-RAF signalling pathway in early flat-type colorectal tumours. Eur J Cancer. 2006; 42:3065-3072. [PubMed: 17011185]

Miyake T, Yoshino K, Enomoto T, Takata T, Ugaki H, Kim A, Fujiwara K, Miyatake T, Fujita M, Kimura T. PIK3CA gene mutations and amplifications in uterine cancers, identified by methods that avoid confounding by PIK3CA pseudogene sequences. Cancer Lett. 2008; 261:120-126. [PubMed: 18180098]

Miyaki M, Iijima T, Yamaguchi T, Takahashi K, Matsumoto H, Yasutome M, Funata N, Mori T. Mutations of the PIK3CA gene in hereditary colorectal cancers. Int J Cancer. 2007; 121:16271630. [PubMed: 17546593]

Mori R, Ishiguro H, Kimura M, Mitsui A, Sasaki H, Tomoda K, Mori Y, Ogawa R, Katada T, Kawano $\mathrm{O}$, et al. PIK3CA mutation status in Japanese esophageal squamous cell carcinoma. J Surg Res. 2008; 145:320-326. [PubMed: 18262558]

Morin PJ, Sparks AB, Korinek V, Barker N, Clevers H, Vogelstein B, Kinzler KW. Activation of betacatenin-Tcf signaling in colon cancer by mutations in beta-catenin or APC. Science. 1997; 275:1787-1790. [PubMed: 9065402]

Mueller W, Mizoguchi M, Silen E, D’Amore K, Nutt CL, Louis DN. Mutations of the PIK3CA gene are rare in human glioblastoma. Acta Neuropathol. 2005; 109:654-655. [PubMed: 15924252]

Muller CI, Miller CW, Hofmann WK, Gross ME, Walsh CS, Kawamata N, Luong QT, Koeffler HP. Rare mutations of the PIK3CA gene in malignancies of the hematopoietic system as well as endometrium, ovary, prostate and osteosarcomas, and discovery of a PIK3CA pseudogene. Leuk Res. 2007; 31:27-32. [PubMed: 16764926] 
Murugan AK, Hong NT, Fukui Y, Munirajan AK, Tsuchida N. Oncogenic mutations of the PIK3CA gene in head and neck squamous cell carcinomas. Int J Oncol. 2008; 32:101-111. [PubMed: 18097548]

Nakayama K, Nakayama N, Kurman RJ, Cope L, Pohl G, Samuels Y, Velculescu VE, Wang TL, Shih Ie M. Sequence mutations and amplification of PIK3CA and AKT2 genes in purified ovarian serous neoplasms. Cancer Biol Ther. 2006; 5:779-785. [PubMed: 16721043]

Oda K, Stokoe D, Taketani Y, McCormick F. High frequency of coexistent mutations of PIK3CA and PTEN genes in endometrial carcinoma. Cancer Res. 2005; 65:10669-10673. [PubMed: 16322209]

Ogino S, Nosho K, Kirkner GJ, Shima K, Irahara N, Kure S, Chan AT, Engelman JA, Kraft P, Cantley $\mathrm{LC}$, et al. PIK3CA mutation is associated with poor prognosis among patients with curatively resected colon cancer. J Clin Oncol. 2009; 27:1477-1484. [PubMed: 19237633]

Okudela K, Suzuki M, Kageyama S, Bunai T, Nagura K, Igarashi H, Takamochi K, Suzuki K, Yamada T, Niwa H, et al. PIK3CA mutation and amplification in human lung cancer. Pathol Int. 2007; 57:664-671. [PubMed: 17803655]

Ollikainen M, Gylling A, Puputti M, Nupponen NN, Abdel-Rahman WM, Butzow R, Peltomaki P. Patterns of PIK3CA alterations in familial colorectal and endometrial carcinoma. Int J Cancer. 2007; 121:915-920. [PubMed: 17471559]

Omholt K, Krockel D, Ringborg U, Hansson J. Mutations of PIK3CA are rare in cutaneous melanoma. Melanoma Res. 2006; 16:197-200. [PubMed: 16567976]

Or YY, Hui AB, To KF, Lam CN, Lo KW. PIK3CA mutations in nasopharyngeal carcinoma. Int J Cancer. 2006; 118:1065-1067. [PubMed: 16114017]

Page C, Huang M, Jin X, Cho K, Lilja J, Reynolds RK, Lin J. Elevated phosphorylation of AKT and Stat3 in prostate, breast, and cervical cancer cells. Int J Oncol. 2000; 17:23-28. [PubMed: 10853013]

Pang JC, Chung NY, Chan NH, Poon WS, Thomas T, Ng HK. Rare mutation of PIK3CA in meningiomas. Acta Neuropathol. 2006; 111:284-285. [PubMed: 16463202]

Parsons DW, Wang TL, Samuels Y, Bardelli A, Cummins JM, DeLong L, Silliman N, Ptak J, Szabo S, Willson JK, et al. Colorectal cancer: mutations in a signalling pathway. Nature. 2005; 436:792. [PubMed: 16094359]

Parsons DW, Jones S, Zhang X, Lin JC, Leary RJ, Angenendt P, Mankoo P, Carter H, Siu IM, Gallia GL, et al. An integrated genomic analysis of human glioblastoma multiforme. Science. 2008; 321:1807-1812. [PubMed: 18772396]

Perez-Tenorio G, Alkhori L, Olsson B, Waltersson MA, Nordenskjold B, Rutqvist LE, Skoog L, Stal O. PIK3CA mutations and PTEN loss correlate with similar prognostic factors and are not mutually exclusive in breast cancer. Clin Cancer Res. 2007; 13:3577-3584. [PubMed: 17575221]

Phillips WA, Russell SE, Ciavarella ML, Choong DY, Montgomery KG, Smith K, Pearson RB, Thomas RJ, Campbell IG. Mutation analysis of PIK3CA and PIK3CB in esophageal cancer and Barrett's esophagus. Int J Cancer. 2006; 118:2644-2646. [PubMed: 16380997]

Philp AJ, Campbell IG, Leet C, Vincan E, Rockman SP, Whitehead RH, Thomas RJ, Phillips WA. The phosphatidylinositol 3'-kinase p85alpha gene is an oncogene in human ovarian and colon tumors. Cancer Res. 2001; 61:7426-7429. [PubMed: 11606375]

Qiu W, Schonleben F, Li X, Ho DJ, Close LG, Manolidis S, Bennett BP, Su GH. PIK3CA mutations in head and neck squamous cell carcinoma. Clin Cancer Res. 2006; 12:1441-1446. [PubMed: 16533766]

Qiu W, Tong GX, Manolidis S, Close LG, Assaad AM, Su GH. Novel mutant-enriched sequencing identified high frequency of PIK3CA mutations in pharyngeal cancer. Int J Cancer. 2008; 122:1189-1194. [PubMed: 17990317]

Rajagopalan H, Bardelli A, Lengauer C, Kinzler KW, Vogelstein B, Velculescu VE. Tumorigenesis: RAF/RAS oncogenes and mismatch-repair status. Nature. 2002; 418:934. [PubMed: 12198537]

Riener MO, Bawohl M, Clavien PA, Jochum W. Rare PIK3CA hotspot mutations in carcinomas of the biliary tract. Genes Chromosomes Cancer. 2008; 47:363-367. [PubMed: 18181165]

Robertson GP, Furnari FB, Miele ME, Glendening MJ, Welch DR, Fountain JW, Lugo TG, Huang HJ, Cavenee WK. In vitro loss of heterozygosity targets the PTEN/MMAC1 gene in melanoma. Proc Natl Acad Sci USA. 1998; 95:9418-9423. [PubMed: 9689095] 
Saal LH, Holm K, Maurer M, Memeo L, Su T, Wang X, Yu JS, Malmstrom PO, Mansukhani M, Enoksson J, et al. PIK3CA mutations correlate with hormone receptors, node metastasis, and ERBB2, and are mutually exclusive with PTEN loss in human breast carcinoma. Cancer Res. 2005; 65:2554-2559. [PubMed: 15805248]

Saal LH, Johansson P, Holm K, Gruvberger-Saal SK, She QB, Maurer M, Koujak S, Ferrando AA, Malmstrom P, Memeo L, et al. Poor prognosis in carcinoma is associated with a gene expression signature of aberrant PTEN tumor suppressor pathway activity. Proc Natl Acad Sci USA. 2007; 104:7564-7569. [PubMed: 17452630]

Samuels Y, Wang Z, Bardelli A, Silliman N, Ptak J, Szabo S, Yan H, Gazdar A, Powell SM, Riggins GJ, et al. High frequency of mutations of the PIK3CA gene in human cancers. Science. 2004; 304:554. [PubMed: 15016963]

Samuels Y, Diaz LA Jr, Schmidt-Kittler O, Cummins JM, Delong L, Cheong I, Rago C, Huso DL, Lengauer C, Kinzler KW, et al. Mutant PIK3CA promotes cell growth and invasion of human cancer cells. Cancer Cell. 2005; 7:561-573. [PubMed: 15950905]

Santarpia L, El-Naggar AK, Cote GJ, Myers JN, Sherman SI. Phosphatidylinositol 3-kinase/ akt and ras/raf-mitogen-activated protein kinase pathway mutations in anaplastic thyroid cancer. J Clin Endocrinol Metab. 2008; 93:278-284. [PubMed: 17989125]

Sartore-Bianchi A, Martini M, Molinari F, Veronese S, Nichelatti M, Artale S, Di Nicolantonio F, Saletti P, De Dosso S, Mazzucchelli L, et al. PIK3CA mutations in colorectal cancer are associated with clinical resistance to EGFR-targeted monoclonal antibodies. Cancer Res. 2009; 69:1851-1857. [PubMed: 19223544]

Schonleben F, Qiu W, Ciau NT, Ho DJ, Li X, Allendorf JD, Remotti HE, Su GH. PIK3CA mutations in intraductal papillary mucinous neoplasm/carcinoma of the pancreas. Clin Cancer Res. 2006; 12:3851-3855. [PubMed: 16778113]

Sharma SV, Bell DW, Settleman J, Haber DA. Epidermal growth factor receptor mutations in lung cancer. Nat Rev Cancer. 2007; 7:169-181. [PubMed: 17318210]

Shayesteh L, Lu Y, Kuo WL, Baldocchi R, Godfrey T, Collins C, Pinkel D, Powell B, Mills GB, Gray JW. PIK3CA is implicated as an oncogene in ovarian cancer. Nat Genet. 1999; 21:99-102. [PubMed: 9916799]

Sjoblom T, Jones S, Wood LD, Parsons DW, Lin J, Barber TD, Mandelker D, Leary RJ, Ptak J, Silliman N, et al. The consensus coding sequences of human breast and colorectal cancers. Science. 2006; 314:268-274. [PubMed: 16959974]

Sparks AB, Morin PJ, Vogelstein B, Kinzler KW. Mutational Analysis of the APC/b-catenin/Tcf Pathway in Colorectal Cancer. Cancer Res. 1998; 58:1130-1134. [PubMed: 9515795]

Staal SP. Molecular cloning of the akt oncogene and its human homologues AKT1 and AKT2: amplification of AKT1 in a primary human gastric adenocarcinoma. Proc Natl Acad Sci USA. 1987; 84:5034-5037. [PubMed: 3037531]

Stahl JM, Sharma A, Cheung M, Zimmerman M, Cheng JQ, Bosenberg MW, Kester M, Sandirasegarane L, Robertson GP. Deregulated Akt3 activity promotes development of malignant melanoma. Cancer Res. 2004; 64:7002-7010. [PubMed: 15466193]

Steck PA, Pershouse MA, Jasser SA, Yung WK, Lin H, Ligon AH, Langford LA, Baumgard ML, Hattier T, Davis T, et al. Identification of a candidate tumour suppressor gene, MMAC1, at chromosome 10q23.3 that is mutated in multiple advanced cancers. Nat Genet. 1997; 15:356362. [PubMed: 9090379]

Stemke-Hale K, Gonzalez-Angulo AM, Lluch A, Neve RM, Kuo WL, Davies M, Carey M, Hu Z, Guan Y, Sahin A, et al. An integrative genomic and proteomic analysis of PIK3CA, PTEN, and AKT mutations in breast cancer. Cancer Res. 2008; 68:6084-6091. [PubMed: 18676830]

Stephens M, Sloan JS, Robertson PD, Scheet P, Nickerson DA. Automating sequence-based detection and genotyping of SNPs from diploid samples. Nat Genet. 2006; 38:375-381. [PubMed: 16493422]

Tanaka Y, Kanai F, Tada M, Asaoka Y, Guleng B, Jazag A, Ohta M, Ikenoue T, Tateishi K, Obi S, et al. Absence of PIK3CA hotspot mutations in hepatocellular carcinoma in Japanese patients. Oncogene. 2006; 25:2950-2952. [PubMed: 16331247] 
Thompson FH, Emerson J, Olson S, Weinstein R, Leavitt SA, Leong SP, Emerson S, Trent JM, Nelson MA, Salmon SE, et al. Cytogenetics of 158 patients with regional or disseminated melanoma. Subset analysis of near-diploid and simple karyotypes. Cancer Genet Cytogenet. 1995; 83:93104. [PubMed: 7553595]

Tsao H, Zhang X, Benoit E, Haluska FG. Identification of PTEN/MMAC1 alterations in uncultured melanomas and melanoma cell lines. Oncogene. 1998; 16:3397-3402. [PubMed: 9692547]

Vanhaesebroeck B, Waterfield MD. Signaling by distinct classes of phosphoinositide 3-kinases. Exp Cell Res. 1999; 253:239-254. [PubMed: 10579926]

Velasco A, Bussaglia E, Pallares J, Dolcet X, Llobet D, Encinas M, Llecha N, Palacios J, Prat J, Matias-Guiu X. PIK3CA gene mutations in endometrial carcinoma: correlation with PTEN and K-RAS alterations. Hum Pathol. 2006; 37:1465-1472. [PubMed: 16949921]

Velho S, Oliveira C, Ferreira A, Ferreira AC, Suriano G, Schwartz S Jr, Duval A, Carneiro F, Machado JC, Hamelin R, Seruca R. The prevalence of PIK3CA mutations in gastric and colon cancer. Eur J Cancer. 2005; 41:1649-1654. [PubMed: 15994075]

Vivanco I, Sawyers CL. The phosphatidylinositol 3-Kinase AKT pathway in human cancer. Nat Rev Cancer. 2002; 2:489-501. [PubMed: 12094235]

Wang Y, Helland A, Holm R, Kristensen GB, Borresen-Dale AL. PIK3CA mutations in advanced ovarian carcinomas. Hum Mutat. 2005; 25:322. [PubMed: 15712344]

Wang Y, Hou P, Yu H, Wang W, Ji M, Zhao S, Yan S, Sun X, Liu D, Shi B, et al. High prevalence and mutual exclusivity of genetic alterations in the phosphatidylinositol-3-kinase/ akt pathway in thyroid tumors. J Clin Endocrinol Metab. 2007; 92:2387-2390. [PubMed: 17426084]

Wood LD, Parsons DW, Jones S, Lin J, Sjoblom T, Leary RJ, Shen D, Boca SM, Barber T, Ptak J, et al. The genomic landscapes of human breast and colorectal cancers. Science. 2007; 318(5853): 1108-1113. [PubMed: 17932254]

Wu G, Mambo E, Guo Z, Hu S, Huang X, Gollin SM, Trink B, Ladenson PW, Sidransky D, Xing M. Uncommon mutation, but common amplifications, of the PIK3CA gene in thyroid tumors. J Clin Endocrinol Metab. 2005a; 90:4688-4693. [PubMed: 15928251]

Wu G, Xing M, Mambo E, Huang X, Liu J, Guo Z, Chatterjee A, Goldenberg D, Gollin SM, Sukumar $\mathrm{S}$, et al. Somatic mutation and gain of copy number of PIK3CA in human breast cancer. Breast Cancer Res. 2005b; 7:R609-R616. [PubMed: 16168105]

Yamamoto H, Shigematsu H, Nomura M, Lockwood WW, Sato M, Okumura N, Soh J, Suzuki M, Wistuba II, Fong KM, et al. PIK3CA mutations and copy number gains in human lung cancers. Cancer Res. 2008; 68:6913-6921. [PubMed: 18757405]

Zhang L, Yang N, Katsaros D, Huang W, Park JW, Fracchioli S, Vezzani C, Rigault de la Longrais IA, Yao W, Rubin SC, Coukos G. The oncogene phosphatidylinositol 3'-kinase catalytic subunit alpha promotes angiogenesis via vascular endothelial growth factor in ovarian carcinoma. Cancer Res. 2003; 63:4225-4231. [PubMed: 12874030]

Zhao L, Vogt PK. Helical domain and kinase domain mutations in p110alpha of phosphatidylinositol 3-kinase induce gain of function by different mechanisms. Proc Natl Acad Sci USA. 2008; 105:2652-2657. [PubMed: 18268322]

Zhou XP, Gimm O, Hampel H, Niemann T, Walker MJ, Eng C. Epigenetic PTEN silencing in malignant melanomas without PTEN mutation. Am J Pathol. 2000; 157:1123-1128. [PubMed: 11021816] 